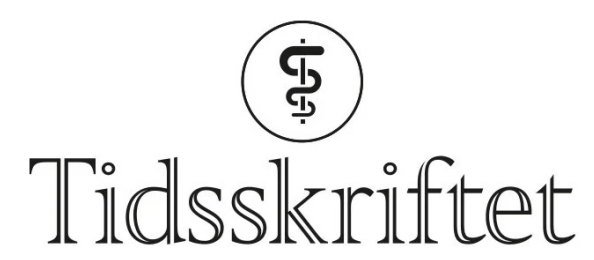

DEN NORSKE LEGEFORENING

\title{
Niels Andreas Stolt-Nielsen
}

\author{
MINNEORD
}

TORBJØRN A. FREDRIKSEN

GEIRMUND UNSGÅRD

JOHAN CAPPELEN

TOMM BROSTRUP MÜLLER

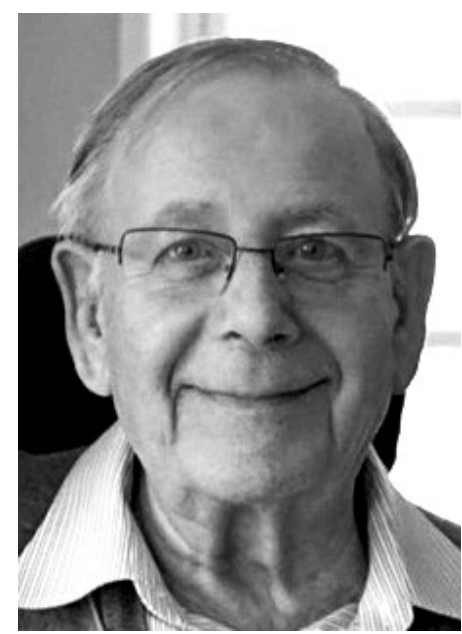

Niels Andreas Stolt-Nielsen døde 5. oktober i år, 8o år gammel. En foregangsmann innen norsk nevrokirurgi har gått bort.

Stolt-Nielsen var født og vokste opp i Haugesund i et miljø preget av skipsfart. Hans interesser gikk allikevel mer i retning av helse og ledet ham til medisinerstudiet i Oslo. Etter turnustjeneste begynte han på sin kirurgiske løpebane ved Regionsykehuset i Troms $\emptyset$ i 1971. I 1976 kom han til Nevrokirurgisk avdeling ved daværende Regionsykehuset i Trondheim (nå St. Olavs Hospital) bare ca. et år etter at avdelingen ble etablert. Avdelingen var da den nordligste i Norge og med tilsvarende meget stort nedslagsfelt. Bemanningen var lav, og arbeidsbelastningen ble svært stor med operasjoner nærmest døgnet rundt. Stolt-Nielsen utmerket seg som en meget dyktig kirurg med god teoretisk bakgrunn, og han steg raskt i gradene. Han ble avdelingsoverlege og sjef for avdelingen i 1986 og fortsatte fram til 1996. Avdelingen var aktiv i å ta i bruk nye teknikker og var først i landet til å ta i 
bruk elektrisk ryggmargstimulering. I løpet av hans tid som leder ble avdelingen også den første i Norge til å innføre mikrokirurgisk teknikk ved ryggoperasjoner, hvilket dramatisk forkortet både operasjons- og liggetid ved den type operasjoner.

Etter endt karriere i Trondheim flyttet han sørover med sin kjære Unni, både for å få mindre belastende arbeidsforhold og for å komme nærmere familien. Han arbeidet ved Askim sykehus og hadde også operative oppgaver ved Ski sykehus og Aker sykehus, men han begrenset virksomheten til rygg- og smertekirurgi.

I 2007 fikk han hjerneslag, og arbeidskarrieren fikk en brå slutt like før pensjonsalder. Familien var ellers sentrum i hans liv. Han og Unni holdt sammen hele livet og fikk fire barn og etter hvert åtte barnebarn. Personlig var Andreas vennlig, omsorgsfull og en meget hyggelig og humoristisk person med stor kontaktflate. Han bevarte humøret til tross for store helsemessige utfordringer og var helt klar i hodet til det siste.

Niels Andreas Stolt-Nielsen var en høyt aktet lege og svært avholdt av sine mange pasienter og deres pårørende. Vi lyser fred over hans minne!

Publisert: 13. desember 2021. Tidsskr Nor Legeforen. DOI: 10.4045/tidsskr.21.0764

(C) Tidsskrift for Den norske legeforening 2023. Lastet ned fra tidsskriftet.no 26. april 2023. 